\title{
Peran Pusat Pelayanan Terpadu Pemberdayaan Perempuan dan Anak (P2TP2A) Dalam Pemberdayaan Korban Kekerasan Dalam Rumah Tangga
}

\author{
Titania Tamaris \\ Jurusan Pendidikan Luar Sekolah, Universitas Negeri Yogyakarta \\ titaniatamaris.2019@student.uny.ac.id
}

Received: 23 Juni 2021; Revised: 28 Juni 2021; Accepted: 29 Juni 2021

\begin{abstract}
This study aims to describe the role of Pusat Layanan Terpadu Pemberdayaan Perempuan dan Anak (P2TP2A) on empowering women victims of domestic violence. This study used a qualitative approach with a descriptive method. Data collection techniques are carried out by studying literature. Data analysis was carried out with an interactive model including data collection, reduction, presentation and conclusion drawing. The results showed that women victims of domestic violence experienced physical and psychological impacts. Physical impacts can include bruises or wounds on the body, broken bones, hair loss, miscarriage, premature birth and disorders of the reproductive organs. Psychological impacts in the form of Post-Traumatic Stress Disorder (PTSD), depression, and anxiety. The empowerment of women victims of domestic violence is carried out based on the legal basis of Undang-Undang Nomor 23 Tahun 2004. The role of P2TP2A includes three stages, namely prevention, treatment, and recovery. The three stages work together to reduce the possibility of domestic violence in the community and provide services for victims.
\end{abstract}

Keywords: Women Empowerment, Domestic Violence, P2TP2A.

\section{ABSTRAK}

Penelitian ini bertujuan untuk mendeskripsikan peran Pusat Pelayanan Terpadu Pemberdayaan Perempuan dan Anak (P2TP2A) dalam pemberdayaan perempuan korban kekerasan dalam rumah tangga. Penelitian ini menggunakan pendekatan kualitatif dengan metode deskriptif. Teknik pengumpulan data dilakukan dengan studi literatur. Analisis data dilakukan dengan model interaktif mencakup pengumpulan data, reduksi, penyajian dan penarikan kesimpulan. Hasil penelitian menunjukkan bahwa perempuan korban kekerasan dalam rumah tangga mengalami dampak secara fisik dan psikis. Dampak fisik dapat berupa memar atau luka di tubuh, patah tulang, kerontokan rambut, keguguran, kelahiran prematur dan gangguan pada organ reproduksi. Dampak psikis berupa Post-Traumatic Stress Disorder (PTSD), depresi, dan kecemasan. Pemberdayaan perempuan korban kekerasan dalam rumah tangga dilakukan berdasarkan landasan hukum Undang-Undang No.23 Tahun 2004. Peran P2TP2A meliputi tiga tahapan yaitu pencegahan, penanganan, dan pemulihan. Ketiga tahapan bersinergi untuk menekan kemungkinan terjadinya KDRT di masyarakat dan melakukan pelayanan bagi korban.

Kata kunci: Pemberdayaan Perempuan, Kekerasan dalam Rumah Tangga, P2TP2A.

(C)2021 Titania Tamaris Under the license CC BY-SA 4.0

\section{PENDAHULUAN}

Memnurut Undang-Undang Nomor 1 Tahun 1974 Pasal 1 perkawinan memiliki pengertian "ikatan lahir batin antara seorang pria dengan seorang wanita 
sebagai suami istri dengan tujuan membentuk keluarga (rumah tangga) yang bahagia dan kekal berdasarkan Ketuhanan Yang Maha Esa”. Sedangkan pendapat lain mengenai pengertian perkawinan menurut Duval \& Miller (Oktarina et al., 2015) "Marriage is a socially recognized relationship between a man and a woman that provides for sexual relation, legitimized childbearing and estabilishing division of labour between spouses". Berdasarkan pendapat tersebut maka dapat disimpulkan bahwasanya istilah perkawinan memiliki makna yang lebih ekstensif dari pada istilah pernikahan. Istilah pernikahan menggambarkan sebuah hubungan suami istri dalam menjalani kehidupan bersama setelah akad, sementara perkawinan lebih mengarah pada urusan yang menjadi konsekuensi dari proses pelaksanaan pernikahan yang meliputi hak kewajiban suami istri, nafkah perceraian, pengasuhan anak, perwalian dan lain-lain.

Dalam agama Islam, perkawinan juga disebut sebagai salah satu cara untuk menyempurnakan agama dan juga menjaga kemaluan. Sebagaimana yang tertuang dalam HR. Bukhari Muslim yaitu:

"Wahai para pemuda! Barangsiapa di antara kalian berkemampuan untuk menikah, maka menikahlah, karena nikah itu lebih menundukkan pandangan, dan lebih membentengi farji (kemaluan). Dan barangsiapa yang tidak mampu, maka hendaklah ia shaum (puasa), karena shaum itu dapat membentengi dirinya”.

Meski memiliki tujuan yang baik, perkawinan dalam perjalanannya pun banyak menghadapi tantangan dan permasalahan tersendiri karena pada kenyataannya tidak mudah menggabungkan visi misi hidup dari hasil rekonstruksi pengalaman dua individu yang berbeda latar pendidikan, ekonomi, sosial, budaya menjadi satu tujuan bersama yang baru. Perbedaan pendapat sampai berdebat mungkin menjadi hal yang umum dalam kehidupan berumah tangga. Namun jika keadaan seperti itu tidak dapat dikendalikan, permasalahan tersebut dapat mengarah pada tindak kekerasan dalam rumah tangga (KDRT). Menurut UndangUndang Nomor 23 Tahun 2004, definisi Kekerasan Dalam Rumah Tangga yaitu:

"Setiap perbuatan terhadap seseorang terutama perempuan, yang berakibat timbulnya kesengsaraan atau penderitaan secara fisik, seksual, psikologis, dan/atau penelantaran rumah tangga termasuk ancaman untuk melakukan perbuatan, pemaksaan, atau perampasan kemerdekaan secara melawan 
hukum dalam lingkup rumah tangga. KDRT dapat diartikan sebagai tindakan kekerasan yang dilakukan oleh seorang pengasuh, orang tua, atau pasangan".

KDRT bukanlah masalah yang hanya dapat dijumpai di Indonesia, tetapi hampir di setiap negara yang ada di dunia. Kekerasan yang terjadi dalam rumah tangga dapat berupa tindakan yang disadari maupun tidak disadari, secara lisan atau perialku, dan dalam skala kecil atau besar. Umumnya kekerasan dalam rumah tangga dialami oleh perempuan. Komnas Perempuan menyebutkan terdapat $79 \%$ atau 6.480 kasus KDRT sepanjang tahun 2020 dengan bentuk kekerasan yang paling banyak adalah kekerasan fisik 2.025 kasus, kekerasan seksual 1.983 kasus, kekerasan psikis 1.792 kasus, dan kekerasan ekonomi 680 kasus (Komnas Perempuan, 2021). Perlu digaris bawahi bahwasanya angka-angka tersebut merupakan kasus yang tercatat oleh Komnas Perempuan sehingga masih ada kemungkinan banyak kasus KDRT yang terjadi di masyarakat tetapi belum terlaporkan. Terdapat banyak faktor baik itu faktor internal ataupun faktor eksternal yang menjadi alasan mengapa korban KDRT tidak melaporkan kasusnya. Terlebih kondisi pandemi Covid-19 yang menyebabkan segala aktivitas masyarakat dibatasi dan seluruh sektor kehidupan mengalami penurunan sehingga masyarakat lebih mudah stres. Data menunjukkan selama pandemi Covid-19, terhitung mulai Maret-Juni 2020 kasus KDRT yang terjadi melampaui setengah kasus KDRT sepanjang tahun 2019 (Nadya Muna et al., 2020).

Berdasarkan keterangan Komnas Perempuan, KDRT dapat terjadi dikarenakan adanya ketidaksetaraan dan ketidakadilan gender. Stigma kuat masyarakat Indonesia masih mengarah pada pandangan mengenai perempuan yang memiliki kedudukan di bawah laki-laki yang menyebabkan posisi dan eksistensi perempuan selalu diminoritaskan. Seakan-akan di antara laki-laki dan perempuan terdapat sifat yang bertentangan namun masih terikat. Misalnya saja, laki-laki dianggap sebagai individu yang mandiri dan kuat. Maka sebaliknya, perempuan akan dianggap sebagai individu yang manja dan lemah. Laki-laki dianggap selalu pantas menjadi pemimpin karena rasional, sedangkan perempuan dianggap tidak mampu karena terlalu emosional. Padahal sifat seperti itu bukanlah 
ciri yang melekat karena jenis kelamin. Laki-laki merasa superior karena memiliki kedudukan yang lebih tinggi sebagai kepala keluarga dan menjadi pencari nafkah utama serta menghidupi individu di bawahnya. Perempuan dianggap sebagai individu yang lemah, tidak dapat melakukan apapun, tidak memiliki potensi, hingga tidak berkesempatan dalam berpartisipasi di kehidupan bermasyarakat. Kondisi ini terus mengarah pada diskriminasi perempuan yang berupa subordinasi yaitu istilah yang mengacu pada penomorduaan peran dan fungsi perempuan akibat dominasi patriarki di masyarakat. Marginalisasi yaitu sikap meminggirkan posisi perempuan terhadap sumber ekonomi sehingga menjadi miskin. Beban ganda yaitu beban kerja yang dilimpahkan kepada perempuan secara berlebih. Stereotipe yaitu penilaian atau cap negatif atas perempuan. Bahkan sampai pada tindak kekerasan (Kementerian PUPR, 2014). Indonesia menempati peringkat keempat tertinggi ketidaksetaraan gender diantara negara ASEAN dengan mencapai 0,453 poin berdasarkan Indeks Ketimpangan Gender (Gender Inequality Index). Ini merupakan angka yang cukup tinggi dari rata-rata negara ASEAN lain yaitu 0,356 poin (Portal AXA, 2020). Dengan demikian sudah sebaiknya masalah ini mendapat perhatian khusus.

Pemerintah sendiri sebenarnya telah memberikan perhatian terhadap fenomena KDRT dengan membuat dan mengesahkan undang-undang penghapusan kekerasan dalam rumah tangga yaitu UU RI No. 23 Tahun 2004. Undang-Undang ini sebagai bentuk jaminan yang diberikan oleh negara bagi perempuan Indonesia sebagai upaya preventif kekerasan dalam rumah tangga, menangani pelaku kekerasan dalam rumah tangga, serta memberikan naungan hukum bagi korban kekerasan dalam rumah tangga. Usaha memberikan perlindungan dan perhatian bagi korban KDRT juga tidak hanya dilakukan oleh pusat melalui undang-undang saja karena terdapat kemungkinan di beberapa daerah pengimplementasian undang-undang ini dirasa kurang signifikan, tetapi dapat dilakukan melalui usaha lain dari bawah dan lebih dekat dengan masyarakat seperti pemberdayaan perempuan. Umumnya, korban KDRT akan mengalami trauma serta merasa hilang kepercayaan diri sehingga upaya pemberdayaan perempuan korban KDRT adalah memberikan perlindungan dan menstimulasi 
psikis korban KDRT serta mengembalikan kepercayaan diri perempuan agar dapat berdaya. Pemberdayaan perempuan korban KDRT harus dilakukan melalui tahapan dan lembaga yang terintegrasi guna menjamin keefektifan kegiatan, misalkan melalui Pusat Pelayanan Terpadu Pemberdayaan Perempuan dan Anak (P2TP2A).

Berdasarkan penjelasan di atas, maka peneliti tertarik untuk menulis tentang peran Pusat Pelayanan Terpadu Pemberdayaan Perempuan dan Anak (P2TP2A) dalam pemberdayaan perempuan korban KDRT.

\section{METODE}

Pendekatan penelitian yang digunakan adalah kualitatif dengan metode deskriptif. Teknik pengumpulan data berupa studi literatur dari berbagai referensi yang relevan dengan topik yang diamati yaitu pemberdayaan perempuan melalui Pusat Pelayanan Terpadu Pemberdayaan Perempuan dan Anak. Data yang terkumpul dianalisis menggunakan teknik analisis data analysis interactive, yaitu proses analisis data dengan tahapan pengumpulan data, reduksi data, penyajian data, dan penarikan kesimpulan atau verifikasi.

\section{HASIL DAN PEMBAHASAN}

\section{Hasil}

Pusat Pelayanan Terpadu Pemberdayaan Perempuan dan Anak (P2TP2A) adalah layanan terpadu di bawah naungan Kementerian Pemberdayaan Perempuan dan Perlindungan Anak Republik Indonesia. Persebaran P2TP2A merata di seluruh provinsi Indonesia. Tujuan dibentuknya layanan ini adalah untuk melindungi perempuan dan anak Indonesia dari segala bentuk diskriminasi dan kekerasan demi mewujudkan rasa aman dan nyaman warga negara sekaligus penegakkan kesetaraan gender di masyarakat. Dalam penanganan kasus KDRT, P2TP2A memiliki peran yang dapat dijadikan langkah pemberdayaan perempuan korban KDRT melalui tahap preventif (pencegahan), tahap represif (penangan), dan tahap kuratif (pemulihan). 


\section{Pembahasan}

\section{Penyebab dan Bentuk-Bentuk Kekerasan Dalam Rumah Tangga (KDRT)}

Fenomena KDRT bukanlah sesuatu yang asing di masyarakat. Sejak dulu, permasalahan ini memang sudah terjadi. KDRT dapat terjadi kepada siapa saja, tidak memandang ras, usia, jenis kelamin, latar belakang pendidikan, status sosial atau sebagainya. Kurangnya "awareness" serta pengetahuan yang minim tentang gejala dan pola KDRT masih menjadi salah satu faktor penyebab terus meningkatnya angka KDRT. Data dari World Health Organization (WHO) mengungkapkan 1 dari 3 wanita di seluruh dunia pernah mengalami kekerasan fisik atau seksual baik yang dilakukan oleh pasangan maupun orang lain. Ironisnya banyak kasus KDRT yang terjadi di masyarakat dan cenderung mengarah pada sikap menyalahkan korban (victim blaming).

Victim blaming adalah suatu kondisi ketika korban suatu kejadian disalahkan atas apa yang dialaminya. Alih-alih mendapat perhatian, korban justru disudutkan dengan berbagai pendapat bahwa yang mengundang kejadian buruk itu terjadi adalah sikap korban itu sendiri. Dalam kasus KDRT, victim blaming dapat memperparah kondisi korban KDRT itu sendiri. Menurut Dr. Anju Hurria, seorang psikiater dan asisten profesor klinis psikiatri anak dan remaja di Universitas California, victim blaming dapat dianggap sebagai trauma sekunder atau serangan sekunder bagi korban kekerasan. Hal ini terjadi karena korban disalahkan atas pelecehan atau kekerasan yang mereka alami. Akan timbul tekanan bagi korban yang memperumit gangguan stress karena seakan-akan mereka menghadapi dua serangan yang berbeda. Dari kondisi tersebut dapat mengarah pada peningkatan percobaan bunuh diri serta mengurangi kemungkinan korban kekerasan melaporkan kejadian serupa di masa mendatang karena ada rasa takut terhadap umpan balik negatif jika ia melaporkannya (O. Schroeder, 2016). Hal demikian lah yang terjadi di Indonesia dan menyebabkan lambatnya efektivitas penanganan korban KDRT. Berdasarkan keterangan Direktur Lembaga Bantuan Hukum Asosisasi Perempuan Indonesia untuk Keadilan, Siti Mazuma menyatakan korban kekerasan seksual yang tidak melaporkan kasusnya sebanyak 80\%. Sebesar $20 \%$ korban khawatir akan mendapat stereotipe negatif, $13 \%$ 
menganggap kepolisian atau lembaga tidak akan membantu, sementara $8 \%$ lainnya merasa tidak cukup penting untuk melaporkan kasus yang dialaminya (Adinda, 2020).

Ihromi (Manumpahi et al., 2016) menyebutkan beberapa penyebab timbulnya kekerasan dalam rumah tangga. Pertama, komunikasi yang kurang baik sehingga keluhan atau masalah dalam hubungan rumah tangga tidak tersampaikan dan menimbulkan konflik yang berujung pada kekerasan. Kedua penyelewengan karena hadirnya pihak ketiga dalam hubungan suami istri. Ketiga, citra diri rendah dan frustasi yang menyebabkan emosi tidak stabil dan rentan melakukan tindak kekerasan. Keempat, perubahan status sosial yang tidak dapat dikendalikan dengan baik dalam keluarga. Kelima, terbiasa melakukan tindak kekerasan sebagai sarana yang cepat untuk menyelesaikan suatu masalah. Selain faktor-faktor tersebut, tentunya masih banyak hal yang dapat memicu munculnya KDRT sebab dalam setiap hubungan rumah tangga intensitas permasalahan dan kedinamisannya berbeda.

Sedangkan (Nadia et al., 2018) mengungkapkan faktor tindak kekerasan dalam rumah tangga dapat berasal dari faktor pelaku dan faktor korban yang diperparah dengan adanya "Dysfunctional Communication" yaitu pola berbicara dan berinteraksi yang mematikan maksud atau makna sebenarnya sehingga menghambat tindakan selanjutnya (Shuler, 2018). Dysfunctional communication juga dapat mempengaruhi kesehatan dan kesejahteraan hubungan secara keseluruhan. Adapun faktor-faktor dari perspektif pelaku yakni sebagai berikut. Pertama, sikap tempramental yang diakibatkan pemikiran yang berkepanjangan dan mendalam tentang peristiwa atau situasi yang memicu kemarahan. Empat faktor yang mempengaruhi sikap tempramental seseorang adalah agresi instumental, agresi impulsif, agresi terlantar yang dipicu, dan agresi sifat umum. Terlebih, kurang baiknya pengendalian diri terhadap sesuatu yang memicu kemarahan dipandang sebagai faktor timbulnya tindak kekerasan dalam rumah tangga. Kedua, penyalahgunaan zat terlarang seperti narkoba, ganja, dan alkohol. Ketiga, menyaksikan dan menjadi korban kekerasan dalam keluarga di masa kecil. Anak-anak yang menyaksikan tindak kekerasan atau menjadi korban kekerasan 
dalam keluarga akan secara tidak sadar "terbiasa" terhadap kekerasan di masa dewasanya. Hal ini sesuai dengan Social Learning Theory yang mengatakan seseorang akan belajar dengan melihat dan meniru. Jika sejak dini individu terbiasa melihat tindak kekerasan baik itu secara fisik atau psikis adalah jalan untuk mengekspresikan kemarahan serta menyelesaikan masalah, maka di kemudian hari ia akan melakukan hal yang serupa. Keempat, ideologi gender yang menjadi cara pandang individu memandang dunia sosial dan membuat keputusan dapat menjadi pemicu tindak KDRT sebab akan ada pendangan suami adalah pencari nafkah utama dan tugas istri harus tetap dirumah menjadi pandangan istri juga dapat mengembangkan potensinya di luar rumah.

Sementara itu, faktor dari perspektif korban adalah sebagai berikut. Pertama, rendahnya kepemilikan sumber daya meliputi pendidikan, pendapatan, dan pekerjaan. Tingkat pendidikan rendah menjadi salah satu faktor pemicu rendahnya pendapatan dan pekerjaan perempuan sehingga mereka akan bergantung sepenuhnya kepada suami. Disinilah kekuatan negosiasi perempuan akan berkurang sehingga dapat memicu suami melakukan KDRT. Kedua, sikap penerimaan terhadap kekerasan perempuan. Menyaksikan kekerasan terhadap perempuan selama masak kanak-kanak dapat mengakibatkan penerimaan sikap pelecehan atau kekerasan terhadap perempuan.

Adapun yang tergolong dalam bentuk kekerasan dalam rumah tangga adalah sebagai berikut.

a. Kekerasan fisik yakni perilaku menyakiti dan menyebabkan rasa sakit atau luka pada tubuh korban misalkan memukul, mencekik, menendang, menampar, meninju.

b. Kekerasan psikis yakni perilaku yang menyebabkan timbulnya rasa takut, hilang percaya diri dan kemampuan individu untuk bertindak, serta mengakibatkan ketidakberdayaan seseorang. Kekerasan psikis dapat terjadi melalui lisan maupun perilaku. Contohnya adalah tindakan mengisolasi, ancaman verbal, intimidasi, penghinaan, pelecehan dan pencemaran nama baik. Kekerasan psikis dapat dikategorikan sebagai jenis kekerasan yang paling sulit untuk diidentifikasi. 
c. Kekerasan seksual yakni perilaku memaksakan hubungan seksual secara sepihak dan tidak wajar terhadap salah seorang dalam lingkup rumah tangga dalam mencapai tujuan komersial maupun tujuan tertentu sehingga mempermalukan dan menghancurkan otonomi seksual korban. Contohnya yaitu pemerkosaan, pemerkosaan berkelompok, penetrasi dengan benda atau senjata, perbudakan seksual, penyiksaan seksual, kehamilan paksa, dan aborsi.

d. Penelantaran rumah tangga yaitu perilaku menelantarkan orang dalam lingkup rumah tangga, sedangkan menurut ketentuan hukum yang sah atau karena adanya persetujuan, ia wajib memberikan segala bentuk penghidupan yang baik dan layak.

\section{Potret Tindak Kekerasan Dalam Rumah Tangga (KDRT) dan Dampaknya Bagi Korban}

World Health Organizaion (WHO) melalui laporannya dengan judul "Covid-19 and Violence Against Women : What the Health Sector or System Can Do" menyebutkan bahwasanya dalam keadaan segenting apapun, termasuk pandemi seperti saat ini, kecenderungan kekerasan terahadap perempuan akan meningkat. Kondisi ini terbukti dengan adanya laporan yang terjadi di China, Inggris, dan Amerika Serikat. Tercatat adanya tiga kali peningkatakan kasus kekerasan terhadap perempuan per Februari 2020 dibandingkan data tahun sebelumnya (World Health Organization, 2020). Kondisi demikian juga terjadi di Tunisia. Kekerasan terhadap perempuan meningkat secara signifikan selama pandemi Covid-19 dan lockdown. Jenis kekerasan yang sering terjadi adalah kekerasan fisik (96\%). Perempuan yang pernah mengalami tindak kekerasan sebelumnya, memiliki resiko yang lebih tinggi (Sediri et al., 2020). Cacatan akhir tahun Lembaga Bantuan Hukum Asosiasi Perempuan Indonesia untuk Keadilan (LBH APIK) Jakarta juga mengalami peningkatan yaitu dari 794 kasus (2019) menjadi 1.178 (2020) dengan kasus pengaduan tindak KDRT berjumlah 418 kasus (Wandari, 2021). Hasil penelitian (McLaren et al., 2020) dari Universitas Flinders juga mengidentifikasi adanya peningkatan beban kerja perempuan selama masa pandemi Covid-19 dengan tidak lagi sekedar menjadi ibu rumah tangga 
yang hanya mengurus keluarga dan rumah, namun juga sebagai guru bagi anakanaknya yang melakukan pembelajaran jarak jauh menambah kerentanan perempuan. Apabila tidak dapat menyelesaikan pekerjaannya dengan baik, mereka rawan mendapat perilaku yang tidak menyenangkan.

Tindak KDRT dapat memberikan dampak pada korban baik secara langsung maupun tidak langsung. Kekerasan fisik dan seksual biasanya memberikan dampak langsung yang terlihat berupa memar atau luka di tubuh, patah tulang, kerontokan rambut, keguguran, kelahiran prematur dan gangguan pada organ reproduksi. Seperti yang dialami AN, seorang ibu muda di Kota Tangerang Selatan yang mengalami kekerasan oleh suaminya. Dikutip dari halaman detik.com (Ariyanto, 2021) AN mengaku dicekik dan ditonjok wajahnya sehingga menimbulkan memar pada bagian tubuhnya. Perilaku kasar suaminya tersebut dilatar belakangi karena AN meminta sang suami untuk membelikan kacang almond agar merangsang ASI, namun sang suami menolak dan melakukan kekerasan. Tindak kekerasan dalam rumah tangga juga dapat menyebabkan dampak jangka panjang pada tubuh korban berupa asma, epilepsi, masalah pencernaan, migrain, hipertensi, dan gangguan kulit (Women's Aid, 2020). Sedangkan dampak tidak langsung kekerasan dalam rumah tangga dapat berupa gangguan mental korban akibat terus menerus mendapat ancaman, tekanan, maupun kekerasan. Diagnosa spesifik yang biasa dialami perempuan korban KDRT adalah Post-Traumatic Stress Disorder (PTSD) yakni gangguan setelah mengalami atau melihat kejadian mengerikan, depresi, dan kecemasan yang dapat membawa perubahan mendalam pada aspek fisiologis, gairah, emosi, kognisi, dan memori (Women's Advocates, 2020). Perubahan yang dialami korban KDRT jika tidak ditangani dengan segera dapat menyebabkan individu tersebut enggan menjalankan kehidupannya kembali. Terlebih jika tindak KDRT sudah berlangsung dalam kurun waktu yang panjang. Hal ini akan menambah beban trauma bagi korban sehingga sulit untuk memulihkannya kembali. 


\section{Perlindungan Hukum Korban Kekerasan Dalam Rumah Tangga (KDRT)}

Sejatinya tindakan KDRT termasuk pelanggaran terhadap Hak Asasi Manusia (HAM) untuk mendapat rasa aman dan bebas dari segala bentuk kekerasan. Maka dari itu, pemerintah mengesahkan UU PKDRT Nomor 23 Tahun 2004 sebagai wujud tanggung jawab negara dalam mencegah terjadinya KDRT di masyarakat, memberikan hukuman bagi pelaku, serta melindungi korban. Pengesahan UU PKDRT sekaligus menegaskan bahwasanya kekerasan dalam rumah tanggga bukan lagi sekedar urusan internal keluarga, melainkan masuk ke dalam ranah urusan negara. Adapun bentuk perlindungan hukum bagi korban kekerasan dalam rumah tangga yang tertuang dalam UU RI No.23 Tahun 2004 tentang PKDRT yaitu Pasal 10 berkenaan dengan hak-hak korban meliputi mendapatkan perlindungan pihak keluarga, kepolisian, kejaksaan, pihak hukum; bantuan kesehatan; kerahasiaan korban; pelayanan oleh pekerja sosial dan rohani. Pasal 11 - Pasal 15 tentang kewajiban pemerintah dan masyarakat dalam upaya preventif tindakan KDRT. Pasal 16 - Pasal 38 tentang bentuk perlindungan bagi korban KDRT. Pasal 39 - Pasal 43 tentang hak korban KDRT untuk mendapat pemulihan. Pasal 44 - Pasal 49 tentang ancaman pidana dan hukuman bagi pelaku KDRT.

Dengan disahkannya UU PKDRT, janganlah sampai hanya dimaknai sebagai peraturan tertulis, namun harus menjadi acuan bagi aparat, lembaga sosial, dan masyarakat luas dalam aksi nyata melindungi dan memfasilitasi korban KDRT.

Peran Pusat Pelayanan Terpadu Pemberdayaan Perempuan dan Anak (P2TP2A) dalam Pemberdayaan Perempuan Korban Kekerasan Dalam Rumah Tangga (KDRT)

Dalam pemberdayaan perempuan korban KDRT, P2TP2A memiliki tiga peranan antara lain:

1. Pencegahan (Tahap Preventif)

Sebagai upaya pencegahan atau langkah awal, dilakukan kegiatan sosialisasi kepada masyarakat luas dengan maksud memberikan gambaran dasar tentang tindak KDRT, mengenalkan bentuk-bentuk kekerasan dalam 
rumah tangga serta hukuman bagi pelaku. Selain sosialisasi dilakukan pula penyuluhan secara berkala guna membiasakan masyarakat berdiskusi tentang topik KDRT sehingga meningkatkan kesadaran pada masyarakat tentang KDRT beserta usaha mencegahnya. Dengan langkah demikian, diharapkan kesadaran masyarakat atas fenomena kekerasan dalam rumah tangga dapat meningkat.

2. Penangangan (Tahap Represif)

Ketika sudah terjadi kekerasan dalam rumah tangga, maka P2TP2A memfasilitasi pelayanan yang meliputi bantuan hukum, rehabilitasi medis dan sosial. Dalam hal ini pendampingan dilakukan melalui proses ligitasi dan non litigasi. Dalam penanganan korban KDRT terdapat beberapa tahapan antara lain:

a. Penyadaran dengan menstimulus pemikiran korban bahwa tindak KDRT telah merampas hak-haknya sebagai individu.

b. Menganalisis masalah agar mengetahui kebutuhan korban secara detail.

c. Menentukan skala prioritas masalah untuk mendahulukan penyelesaian bagian "penting" di awal.

d. Berkoordinasi dengan bidang layanan terkait.

e. Melaksanakan tindakan nyata terhadap korban KDRT.

Selain tahap-tahap di atas, P2TP2A juga dapat melakukan pelayanan yang meliputi pelayanan pengaduan, kesehatan (bagi korban KDRT secara fisik), rehabilitasi sosial, perlindungan hukum, pemulangan serta reintegrasi sosial.

3. Pemulihan (Tahap Kuratif)

Dalam tahap pemulihan inilah pemberdayaan perempuan korban KDRT dilakukan. Pemulihan bertujuan untuk mengembalikan korban ke keadaan semula secara psikis maupun fisik sehingga korban dapat kembali menjalankan peran individu atau peran dalam masyarakat. Pemberdayaan dilakukan melalui pelatihan agar korban KDRT secara sadar dapat mandiri mengoptimalkan potensinya dalam bidang-bidang kehidupan. Umumnya pelatihan yang dilakukan adalah pelatihan memasak, home industry, menjahit, menyulam, 
berkebun atau keterampilan lain yang bermanfaat. Pelatihan yang didesain dengan mengkombinasikan komponen psikososial dan strategi ekonomi menjadi lebih efektif untuk meningkatkan status pemberdayaan perempuan korban kekerasan dalam rumah tangga sebab perubahan kesejahteraan finansial individu akan mempengaruhi tingkat kemandirian perempuan. Pelatihan juga dapat menjadi stimulus pengobatan trauma sehingga harapannya individu dapat menyalurkan dan mengubah rasa trauma yang dialami menjadi pengalaman belajar yang bermanfaat dalam menjalani hidupnya sebagai perempuan yang mandiri dan berdaya.

\section{Kendala Pemberdayaan Perempuan Korban Kekerasan Dalam Rumah Tangga (KDRT)}

Menurut (Sari \& Haryani Putri, 2020) terdapat beberapa faktor yang menyebabkan maraknya tindak kekerasan dalam rumah tangga dan menyusahkan korban mendapat pertolongan. Pertama, kesenjangan yang terjadi diantara lakilaki dan perempuan dalam lingkup rumah tangga atau masyarakat umum. Stigma kuat yang berkembang di masyarakat yakni suami merupakan "penguasa" keluarga sehingga istri harus selalu patuh dan menuruti seluruh keinginan suami. Semua yang dilakukan istri harus berada di bawah penguasaan dan kontrol suami yang terkadang semena-mena melakukan kekerasan. Kedua, dependensi penuh istri kepada suami dalam masalah ekonomi. Hal ini menyebabkan ketidakmandirian atau ketidakberdayaan istri sehingga posisinya di dalam keluarga dipandang tidak mampu melakukan apa-apa atau lemah. Kondisi ini dapat memicu suami lebih rentan melakukan tindak kekerasan terhadap istri sebagai pelampiasan. Ketiga, sikap acuh masyarakat yang masih mengabaikan dan memandang tindak KDRT adalah hal yang sepele dan biasa terjadi dalam lingkup keluarga sehingga enggan membantu atau "repot-repot" mengurusnya. Keempat, kesadaran magis berupa kepercayaan bahwasanya takdir perempuan adalah mengalah dan bersabar terhadap segala persoalan dalam rumah tangganya agar bisa menjadi istri yang taat serta untuk menghindari perceraian. Kelima, tindak KDRT yang dialami perempuan dianggap sebagai aib sehingga harus ditutupi. Keenam, kurangnya simpati masyarakat dengan memandang buruk, 
menggunjing serta menjauhkan korban KDRT sehingga korban menjadi kurang terbuka atas kejadian yang dialaminya dan tidak segera mendapat bantuan hukum atau sosial.

\section{SIMPULAN}

Tindak kekerasan dalam rumah tangga yang kerap "menghantui" perempuan dalam menjalani dan membina kehidupan berumah tangga adalah masalah yang serius. Terdapat banyak faktor baik itu secara internal maupun eksternal yang dapat memicu tindak KDRT. Butuh perhatian khusus bagi mereka yang mengalami tindak kekerasan dalam rumah tangga untuk kembali ke keadaan semula baik secara fisik maupun psikis, tidak hanya dari anggota keluarga, melainkan juga dari masyarakat, lembaga terkait, dan pemerintah. Disahkannya Undang-Undang Nomor 23 Tahun 2004 tentang Penghapusan Kekerasan Dalam Rumah Tangga merupakan jaminan pasti bagi warga negara. Dibentuknya pusat layanan yang terintegrasi yakni Pusat Pelayanan Terpadu Pemberdayaan Perempuan dan Anak (P2TP2A) yang juga mengurusi terkait pelayanan bagi perempuan korban tindak KDRT. Adapun peranan P2TP2A dalam pemberdayaan perempuan korban kekerasan dalam rumah tangga meliputi tiga hal yaitu pencegahan, penanganan, dan pemulihan. Tujuannya agar hak-hak korban KDRT dapat terpenuhi serta mampu membangun kehidupannya kembali dengan baik tanpa ancaman dari apapun dan siapapun.

\section{DAFTAR PUSTAKA}

Adinda, P. (2020). Kenapa Korban Kekerasan Seksual Enggan Melaporkan Kasusnya? | Asumsi. https://asumsi.co/post/kenapa-korban-kekerasanseksual-enggan-melaporkan-kasusnya

Ariyanto, R. (2021). Minta Cemilan buat Menambah ASI, Ibu Muda di Tangsel Dianiaya Suami. https://news.detik.com/berita/d-5538207/minta-cemilanbuat-menambah-asi-ibu-muda-di-tangsel-dianiayasuami?_ga=2.28145148.177064301.1620660260-748425642.1615831205

Kementerian PUPR. (2014). Responsive Gender. https://pugpupr.pu.go.id/content/show/42/glosary 
Komnas Perempuan. (2021). Komnas Perempuan. https://komnasperempuan.go.id/siaran-pers-detail/catahu-2020-komnasperempuan-lembar-fakta-dan-poin-kunci-5-maret-2021

Manumpahi, E., Y.V.I Goni, S., \& W. Pongoh, H. (2016). KAJIAN KEKERASAN DALAM RUMAH TANGGA TERHADAP PSIKOLOGI ANAK DI DESA SOAKONORA KECAMATAN JAILOLO KABUPATEN HALMAHERA BARAT. E-Journal Acta Diurna, 5(1).

McLaren, H. J., Wong, K. R., Nguyen, K. N., \& Mahamadachchi, K. N. D. (2020). Covid-19 and women's triple burden: Vignettes from Sri Lanka, Malaysia, Vietnam and Australia. Social Sciences, 9(5). https://doi.org/10.3390/SOCSCI9050087

Nadia, N., Astrah, S., Ishak, M., Abd Wahid, N., \& Abu Yazid Nadiah, Z. (2018). FACTORS AFFECTING DOMESTIC VIOLENCE AGAINST WOMEN: A CONCEPTUAL MODEL AND RESEARCH PROPOSITIONS. International Journal for Studies on Children, Women, Elderly And Disabled, 4.

Nadya Muna, A., Tasya Belinda Rauf, D., \& Krismantari, I. (2020). Angka KDRT di Indonesia meningkat sejak pandemi COVID-19: penyebab dan cara mengatasinya. https://theconversation.com/angka-kdrt-di-indonesiameningkat-sejak-pandemi-covid-19-penyebab-dan-cara-mengatasinya144001

O. Schroeder, M. (2016). The Psychological Impact of Victim Blaming and How to Stop It. https://health.usnews.com/wellness/articles/2016-04-19/thepsychological-impact-of-victim-blaming-and-how-to-stop-it

Oktarina, L. P., Wijaya, M., \& Demartoto, A. (2015). PEMAKNAAN PERKAWINAN: Studi Kasus Pada Perempuan lajang Yang BekerjaDi Kecamatan Bulukerto Kabupaten Wonogiri. Jurnal Analisa Sosiologi, 4(1). https://doi.org/10.20961/jas.v4i1.17412

Portal AXA. (2020). Ketidaksetaraan Gender di Indonesia. https://portal.axa.co.id/direct/Tips/Detail/ketidaksetaraan-gender-diindonesia?Category=Lifestyle

Sari, A., \& Haryani Putri, A. (2020). Perlindungan Hukum Terhadap Perempuan Korban Kekerasan Dalam Rumah Tangga. 14(2). https://doi.org/10.31599/krtha.v14i2.291

Sediri, S., Zgueb, Y., \& Ouanes, S. (2020). Women's mental health: acute impact of COVID-19 pandemic on domestic violence. 749-756. https://doi.org/10.1007/s00737-020-01082-4 
Shuler, M. (2018). Dysfunctional Communication Styles. https://www.theshulergroupllc.com/dysfunctional-communication-stylespart-1/

UNDANG-UNDANG REPUBLIK INDONESIA NOMOR 23 TAHUN 2004 TENTANG PENGHAPUSAN KEKERASAN DALAM RUMAH TANGGA, (2004). https://www.dpr.go.id/dokjdih/document/uu/24.pdf

Wandari, S. (2021). Aduan Kasus Kekerasan di LBH APIK Jakarta Meningkat Sepanjang 2020. https://mediaindonesia.com/humaniora/374987/aduankasus-kekerasan-di-lbh-apik-jakarta-meningkat-sepanjang-2020

Women's Advocates. (2020). Loss of Agency: How Domestic Violence Impacts Mental Health - Women's Advocates - Women's Advocates. https://www.wadvocates.org/2020/05/26/loss-of-agency-how-domesticviolence-impacts-mental-health/

Women's Aid. (2020). Domestic abuse and your physical health - Womens Aid. https://www.womensaid.org.uk/the-survivors-handbook/domestic-abuse-andyour-physical-health/

World Health Organization. (2020). COVID-19 AND VIOLENCE AGAINST WOMEN: WHAT THE HEALTH SECTOR/SYSTEM CAN DO. https://apps.who.int/iris/handle/10665/331699 